\title{
Dissolved methane during hypoxic events at the Boknis Eck time series station (Eckernförde Bay, SW Baltic Sea)
}

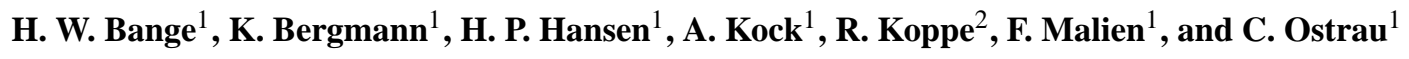 \\ ${ }^{1}$ Forschungsbereich Marine Biogeochemie, IFM-GEOMAR, Leibniz-Institut für Meereswissenschaften, Düsternbrooker Weg \\ 20, 24105 Kiel, Germany \\ ${ }^{2}$ Forschungsbereich Marine Ökologie, IFM-GEOMAR, Leibniz-Institut für Meereswissenschaften, Düsternbrooker Weg 20, \\ 24105 Kiel, Germany
}

Received: 4 November 2009 - Published in Biogeosciences Discuss.: 9 December 2009

Revised: 31 March 2010 - Accepted: 1 April 2010 - Published: 19 April 2010

\begin{abstract}
Dissolved $\mathrm{CH}_{4}$ was measured in the water column at the Boknis Eck (BE) time series station in the Eckernförde Bay (SW Baltic Sea) on a monthly basis from June 2006 to November 2008. The water column at BE was always supersaturated with $\mathrm{CH}_{4}$ and, therefore, $\mathrm{CH}_{4}$ was released to the atmosphere throughout the sampling period: the mean $\mathrm{CH}_{4}$ surface $(1 \mathrm{~m})$ saturation at $\mathrm{BE}$ was $554 \pm 317 \%$. A pulse of enhanced $\mathrm{CH}_{4}$ emissions occurs when the $\mathrm{CH}_{4}$ accumulation in the hypoxic bottom layer during summer is terminated in late summer/autumn. We did not detect a straightforward relationship between periods of enhanced $\mathrm{CH}_{4}$ in the bottom layer and hypoxic events at BE: the sedimentary release of $\mathrm{CH}_{4}$ seemed to be mainly triggered by sedimenting organic material from phytoplankton blooms. We conclude that future $\mathrm{CH}_{4}$ emissions from $\mathrm{BE}$ will be determined by the intensity of phytoplankton blooms, which in turn will be influenced by eutrophication. However, hypoxic events seem to have only a modulating effect on the enhancement of sedimentary methanogenesis and the subsequent release of $\mathrm{CH}_{4}$ to the water column.
\end{abstract}

\section{Introduction}

The worldwide increasing number of coastal areas with extremely (persistent or temporary) depleted dissolved oxygen $\left(\mathrm{O}_{2}\right)$ concentrations $\left[\mathrm{O}_{2}\right]$ has received considerable scientific and public attention during the last few years (Diaz and
Rosenberg, 2008; Rabalais et al., 2009; UNEP, 2004). Socalled coastal hypoxic events or hypoxia occur when $\left[\mathrm{O}_{2}\right]$ falls below $\sim 90 \mu \mathrm{mol} \mathrm{L}^{-1}\left(2 \mathrm{mLL}^{-1}\right)$ (Diaz and Rosenberg, 2008). Anoxic conditions are defined by $\left[\mathrm{O}_{2}\right]=0 \mu \mathrm{mol} \mathrm{L}-1$ and the occurrence of dissolved hydrogen sulphide $\left(\mathrm{H}_{2} \mathrm{~S}\right)$ (Naqvi et al., 2009). The increasing number of coastal hypoxic zones is attributed mainly to increasing nutrient inputs (i.e. eutrophication) by anthropogenic activities (UNEP, 2006). The duration and actual $\left[\mathrm{O}_{2}\right]$ of hypoxia and anoxia have profound influences on both ecosystems and biogeochemical cycles in coastal zones (Diaz and Rosenberg, 2008; Malakoff, 1998). This is especially alarming in view of the fact that the microbial formation (methanogenesis) of the climate-relevant trace gas methane $\left(\mathrm{CH}_{4}\right)$ is a strictly anaerobic process which is favoured under hypoxic and anoxic conditions in the water column as well as in the sediments (Cicerone and Oremland, 1988). However, to what extent the ongoing expansion of eutrophication-induced hypoxia is going to lead to (i) an increase in $\left[\mathrm{CH}_{4}\right]$ in coastal waters and (ii) a possible enhancement of $\mathrm{CH}_{4}$ emissions to the atmosphere is not clear (Bange, 2006; Naqvi et al., 2009).

We measured $\mathrm{CH}_{4}$ in the water column at the Boknis Eck coastal time series station in the Eckernförde Bay (SW Baltic Sea) on a monthly basis from June 2006 to November 2008. Because of seasonally occurring hypoxic events, Boknis Eck provides an ideal natural laboratory to investigate the effects of coastal hypoxia on the distribution of dissolved $\mathrm{CH}_{4}$.

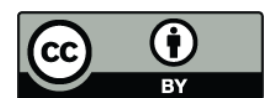

Correspondence to: $\mathrm{H}$. W. Bange

(hbange@ifm-geomar.de)

Published by Copernicus Publications on behalf of the European Geosciences Union. 


\section{Study site description}

The time series station Boknis Eck (BE) is located at the entrance of the Eckernförde Bay $\left(54^{\circ} 31^{\prime} \mathrm{N}, 10^{\circ} 02^{\prime} \mathrm{E}\right.$; Fig. 1) and has a water depth of about $28 \mathrm{~m}$. The hydrographic setting of BE is dominated by the inflow of North Sea water through the Kattegat and the Great Belt. Seasonal stratification is associated with the development of a pycnocline at about $15 \mathrm{~m}$ water depth from mid of March until mid of September. During this period, vertical mixing is restricted and bacterial decomposition of organic material in the deep layer causes pronounced hypoxia and sporadically occurring anoxia during late summer (Hansen et al., 1999). Pronounced phytoplankton blooms occur regularly in autumn (September-November) and spring (February/March) and to a lesser extent during summer (July/August) (Smetacek, 1985). The autumn and spring blooms are followed by pronounced sedimentation of organic material with $>75 \%$ (autumn) and $>50 \%$ (spring) of the total production being sedimented (Smetacek et al., 1984). The summer blooms can be associated with a short period of pronounced sedimentation as well, however, sedimentation during the summer months is generally lower ( $<25 \%$ of the total production) compared to the sedimentation events in autumn and spring (Smetacek et al., 1984).

\section{Methods}

Concentrations of dissolved $\mathrm{CH}_{4}\left[\mathrm{CH}_{4}\right]$ were measured with a static equilibration method: $25 \mathrm{~mL}$ glass vials were filled bubble-free and immediately poisoned with $\mathrm{HgCl}_{2}$ (aq). The samples were usually analyzed within $24 \mathrm{~h}$ after sampling, however, on some occasions samples had to be stored and were measured within a few weeks after sampling. After replacing $10 \mathrm{~mL}$ of the water sample with helium, the samples were allowed to equilibrate for at least $2 \mathrm{~h}$. A $9 \mathrm{~mL}$ subsample of the headspace was used to flush a $2 \mathrm{~mL}$ sample loop. The volume of the sample loop was then injected onto a packed stainless steel column filled with molsieve 5A for isothermal gas chromatographic separation. Detection of $\mathrm{CH}_{4}$ was done with a flame ionization detector. Further details of the method are described in Kock (2007). Two-point calibration curves were prepared daily before and after the measurements of the samples. For the calibration we used two standard gas mixtures of $1.779 \pm 0.002$ and $2.543 \pm 0.002 \mathrm{ppm} \mathrm{CH}_{4}$ in synthetic air. The gravimetrically prepared gas standards (made by DEUSTE Steininger $\mathrm{GmbH}$, Mühlhausen, Germany) were calibrated against the actual NOAA standard scale (Dlugokencky et al., 2005) in the laboratories of the Max Planck Institute for Biogeochemistry in Jena, Germany. $\left[\mathrm{CH}_{4}\right]$ in $\mathrm{nmol} \mathrm{L}^{-1}$ was calculated with

$\left[\mathrm{CH}_{4}\right]=x^{\prime} P V_{h s} /\left(\mathrm{RTV}_{w p}\right)+x^{\prime} \beta P$

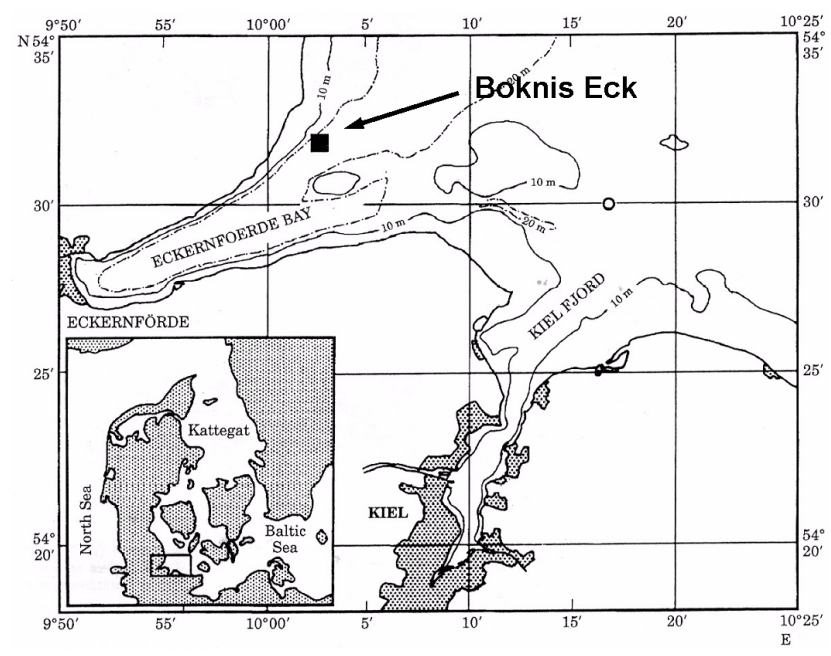

Fig. 1. Location (black square) of the time series station Boknis Eck in the Eckernförde Bay (SW Baltic Sea).

where $x^{\prime}$ is the dry mole fraction of $\mathrm{CH}_{4}$ in the headspace, $P$ is the ambient pressure (set to $10^{5} \mathrm{~Pa}$ ), $V_{h s}$ and $V_{w p}$ are the volumes of the headspace and the water phase, respectively. $R$ stands for the gas constant $\left(8.31451 \mathrm{~m}^{3} \mathrm{~Pa} \mathrm{~K}^{-1} \mathrm{~mol}^{-1}\right), T$ is the temperature during equilibration and $\beta$ is the Bunsen solubility of $\mathrm{CH}_{4}$ (Wiesenburg and Guinasso Jr., 1979). $\mathrm{CH}_{4}$ saturations (Sat in \%) are expressed as

Sat $=100\left[\mathrm{CH}_{4}\right] /\left[\mathrm{CH}_{4}\right]_{e q}$

where $\left[\mathrm{CH}_{4}\right]_{e q}$ is the equilibrium concentration calculated with the in-situ temperature and salinity at $\mathrm{BE}$ and an atmospheric $\mathrm{CH}_{4}$ dry mole fraction of $1.85 \mathrm{ppm}$, which was considered to be a representative mean for the Baltic Sea region from 2006 to 2008 (Rigby et al., 2008).

Triplicate water samples for the determination of $\left[\mathrm{CH}_{4}\right]$ were taken on a monthly basis from six standard depths $(1,5,10,15,20$ and $25 \mathrm{~m})$ with a $5 \mathrm{~L}$ Niskin bottle. The standard deviation was approximated with $\left(\left[\mathrm{CH}_{4}\right]_{\max }\right.$ - $\left.\left[\mathrm{CH}_{4}\right]_{\min }\right) / 1.91$, where $\left[\mathrm{CH}_{4}\right]_{\min }$ and $\left[\mathrm{CH}_{4}\right]_{\max }$ stand for the minimal and maximal $\mathrm{CH}_{4}$ concentrations of the triplicate samples. The factor 1.91 is derived from the statistical method by David (1951). Triplicates with a standard deviation of $>10 \%$ were omitted. The mean analytical error of $\left[\mathrm{CH}_{4}\right]$ was $\pm 4.7 \%$.

Concentrations of dissolved $\mathrm{O}_{2}$ and chlorophyll a were determined using standard methods (Grasshoff et al., 1999). Water temperature and salinity were taken from the monthly routine CTD measurements at BE. Water transparency was measured with a Secchi disk ( $\sim 30 \mathrm{~cm}$ in diameter, white).

The $\mathrm{CH}_{4}$ release to the atmosphere was calculated with

$F_{\text {ase }}=k_{w} \cdot 60 \cdot 60 \cdot 24 \cdot\left(S c_{\mathrm{CH}_{4}} / 600\right)^{-0.5}\left(\left[\mathrm{CH}_{4}\right]-\left[\mathrm{CH}_{4}\right]_{e q}\right)$

where $F_{\text {ase }}$ is the flux density in $\mu \mathrm{mol} \mathrm{m}{ }^{-2} \mathrm{~d}^{-1}, k_{w}$ is the gas transfer coefficient (see below) and $S c$ is the Schmidt 
number which was calculated as the ratio of the kinematic viscosity of seawater (Siedler and Peters, 1986) and the diffusion of $\mathrm{CH}_{4}$ in seawater (Jähne et al., 1987). $S c_{\mathrm{CH}_{4}}$ was calculated with the medians of the surface $(1 \mathrm{~m})$ water temperature $\left(11.2^{\circ} \mathrm{C}\right)$ and salinity (16.8). For $k_{w}$ we used $0.65 \times 10^{-5} \mathrm{~m} \mathrm{~s}^{-1}$ as a lower limit and $1.51 \times 10^{-5} \mathrm{~m} \mathrm{~s}^{-1}$ as an upper limit as recommended by Raymond and Cole (2001) for calculations of flux densities in estuaries. $\left[\mathrm{CH}_{4}\right]$ was computed as the median of all measurements at $1 \mathrm{~m}$ depth $(14.4 \mathrm{nmol} \mathrm{L}-1)$ and $\left[\mathrm{CH}_{4}\right]_{e q}$ was calculated as the median of the equilibrium concentrations in $1 \mathrm{~m}\left(3.1 \mathrm{nmol} \mathrm{L}^{-1}\right)$.

The data presented here are archived in MEMENTO (The Marine Methane and Nitrous Oxide Database) (Bange et al., 2009) and are available from the corresponding author upon request.

\section{Results and discussion}

Three hypoxic events with $\left[\mathrm{O}_{2}\right]<90 \mu \mathrm{mol} \mathrm{L}{ }^{-1}$ have been observed at BE from 2006 to 2008 (Fig. 2). The most pronounced event was observed in 2007 when $\left[\mathrm{O}_{2}\right]$ in the deep layer already started to drop below the threshold in May. The hypoxia in 2007 lasted until November and was most intense in September when the waters became anoxic as indicated by the occurrence of $\mathrm{H}_{2} \mathrm{~S}$ in the bottom layer $(25 \mathrm{~m})$. The hypoxic events in 2006 and 2008 were much shorter and less intense than in 2007: they lasted from August to November in 2006 and August to September 2008. The lowest $\left[\mathrm{O}_{2}\right]$ values observed during the 2006 and 2008 hypoxia were 6.0 and $6.1 \mu \mathrm{mol} \mathrm{L}{ }^{-1}$, respectively.

The fall and spring phytoplankton blooms in 2006/2007 and 2007/2008 could be easily identified by the considerably enhanced chlorophyll a concentrations, whereas the summer blooms in 2007 and 2008 showed only slightly enhanced chlorophyll concentrations (Fig. 2). The Secchi depth measurements showed a reduced water transparency of only $\sim 3 \mathrm{~m}$ and $\sim 4 \mathrm{~m}$ in February and March 2007, respectively, which were the lowest Secchi depths measured during the sampling period from June 2006 to November 2008. Because BE is not influenced by any river plumes, a reduced transparency could be caused only by living phytoplankton as well as dead organisms and other decaying organic material. We conclude therefore, that the sedimentation event in spring 2007 was more pronounced than the sedimentation event in spring 2008 and resulted in comparably higher $\mathrm{O}_{2}$ consumption during remineralisation, which in turn caused the pronounced hypoxic event in 2007.

The time series of $\mathrm{CH}_{4}$ is shown in Fig. 2. $\mathrm{CH}_{4}$ concentrations were in the range from $6.6 \pm 0.2 \mathrm{nmol} \mathrm{L}^{-1}(=178 \%$ saturation in $5 \mathrm{~m}$ in February 2008) to $235 \pm 17.4 \mathrm{nmol} \mathrm{L}^{-1}$ (=8340\% saturation at $20 \mathrm{~m}$ in October 2007). The mean $\mathrm{CH}_{4}$ surface $(1 \mathrm{~m})$ saturation at BE was $554 \pm 317 \%$. Our findings are in agreement with the measurements of Bussmann
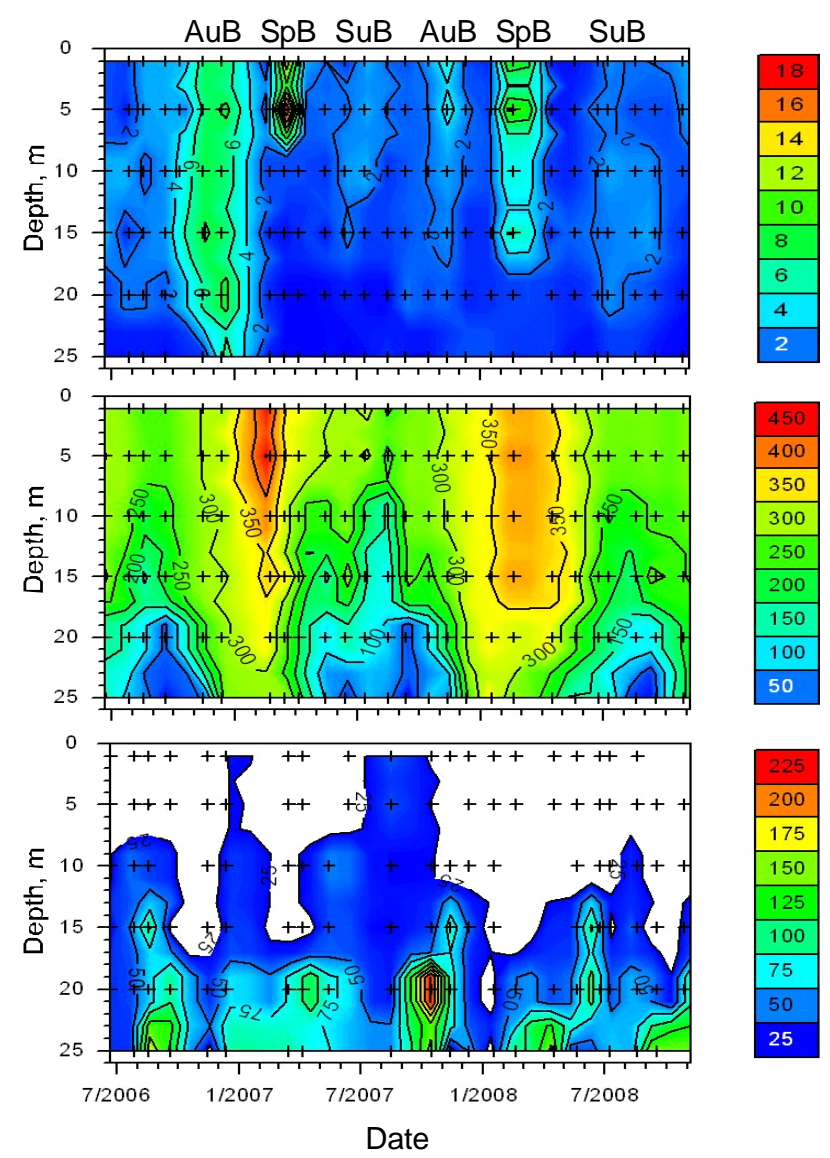

Fig. 2. Time series of chlorophyll a in $\mu g \mathrm{~L}^{-1}$ (upper panel), $\left[\mathrm{O}_{2}\right]$ in $\mu \mathrm{mol} \mathrm{L}{ }^{-1}$ (central panel) and $\left[\mathrm{CH}_{4}\right]$ in nmol L${ }^{-1}$ (lower panel) at the Boknis Eck time series station. Crosses mark the available measurements. Phytoplankton blooms are indicated: AuB, autumn bloom; SpB, spring bloom; $\mathrm{SuB}$, summer bloom. On the $\mathrm{X}$-axis the date is given as m/yyyy (e.g., 1/2007 stands for 1 January 2007).

and Suess (1998) at two stations in the southern part of Eckernförde Bay during February 1993 and May 1994. They found $\left[\mathrm{CH}_{4}\right]$ in the surface layer $(1 \mathrm{~m})$ in the range from 2.1 to $2815 \mathrm{nmol} \mathrm{L}^{-1}$. Comparable $\mathrm{CH}_{4}$ saturations have been observed in other coastal areas of the Baltic Sea. From the Bodden Waters (southern Baltic Sea), for example, a seasonality of the $\mathrm{CH}_{4}$ saturations in the range from 105 to $15500 \%$ have been reported (Bange et al. 1998). $\mathrm{CH}_{4}$ saturations in the open Baltic Sea (Baltic Proper) range from 113-395\% (Bange et al., 1994) and are lower than those observed in coastal areas of the Baltic Sea. Our measurements at BE are in line with the view that the Baltic Sea is a significant regional source of atmospheric $\mathrm{CH}_{4}$ (Bange, 2006).

The water column at $\mathrm{BE}$ was always supersaturated with $\mathrm{CH}_{4}$ (Fig. 3) and, therefore, $\mathrm{CH}_{4}$ was released to the atmosphere throughout the sampling period (for an estimate of the sea-to-air flux density see below). The seasonality of the mean monthly $\mathrm{CH}_{4}$ surface $(1 \mathrm{~m})$ saturation is shown in 


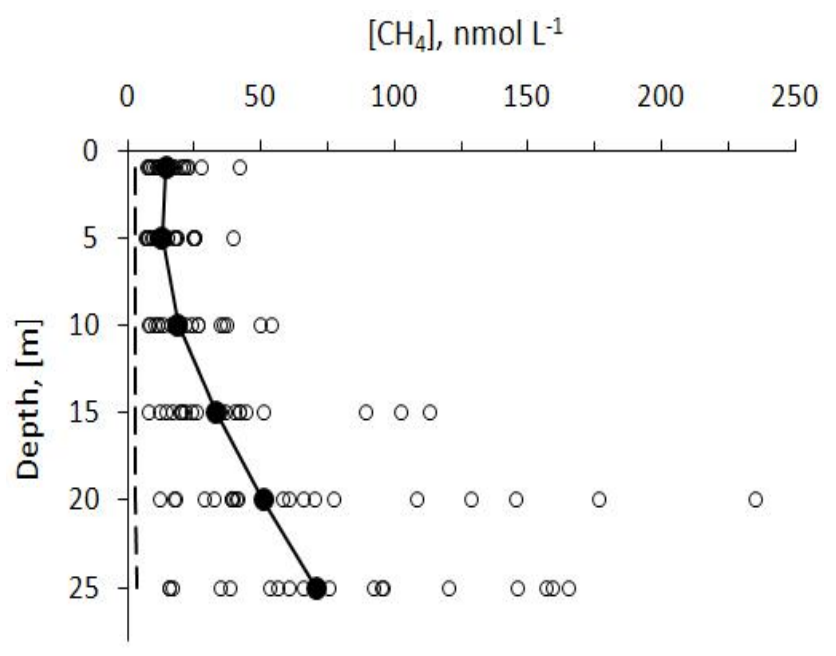

Fig. 3. Depth distribution of $\mathrm{CH}_{4}$ at Boknis Eck (all data, open circles). The bold line indicates the mean $\mathrm{CH}_{4}$ profile based on the median values calculated for each depth. The dashed line indicates the corresponding $\mathrm{CH}_{4}$ equilibrium concentrations.

Fig. 4. It is obvious that the mean $\mathrm{CH}_{4}$ surface saturations are considerably enhanced (up to 1076\%) from late summer to winter. This indicates that there is a pulse of high $\mathrm{CH}_{4}$ emissions to the atmosphere when the accumulation of $\mathrm{CH}_{4}$ in the hypoxic/anoxic bottom layer during summer stratification is terminated in late summer/autumn.

It is well known that the sediments of the Eckernförde Bay are sites of high $\mathrm{CH}_{4}$ accumulation resulting from methanogenesis which, in turn, is fuelled by the high amount of organic material in the sediments (Abegg and Anderson, 1997; Treude et al., 2005; Whiticar, 2002). The $\mathrm{CH}_{4}$ in the Eckernförde Bay sediments does not come from the underlying Schwedeneck petroleum reservoir (Whiticar, 2002). Despite the fact that at $\mathrm{BE}$ anaerobic $\mathrm{CH}_{4}$ oxidation in the sediments can effectively prevent the $\mathrm{CH}_{4}$ release to the water column (Treude et al., 2005), some of the $\mathrm{CH}_{4}$ obviously is released via ebullition (Jackson et al., 1998). In the Eckernförde Bay $\mathrm{CH}_{4}$ can be also released to the water column from pockmark structures during episodes of groundwater efflux (Bussmann and Suess, 1998), however, the majority of the pockmarks are found in the southern part of Eckernförde Bay (Whiticar, 2002) and, therefore, a $\mathrm{CH}_{4}$ contribution via groundwater is negligible at BE. Moreover, we did not find any signs of groundwater release in the salinity data of BE. In view of the discussion above we conclude that $\mathrm{CH}_{4}$ in the water column of $\mathrm{BE}$ is dominated by its release from the sediments.

From the data in Fig. 2 it is obvious those periods with enhanced $\left[\mathrm{CH}_{4}\right]$ in the bottom layers are not correlated with the hypoxic events. This was confirmed by statistical analysis which did not reveal any statistical significant correlation between $\left[\mathrm{O}_{2}\right]$ and $\left[\mathrm{CH}_{4}\right]$. In order to find out whether the observed variability of $\left[\mathrm{CH}_{4}\right]$ might be caused by the sea-

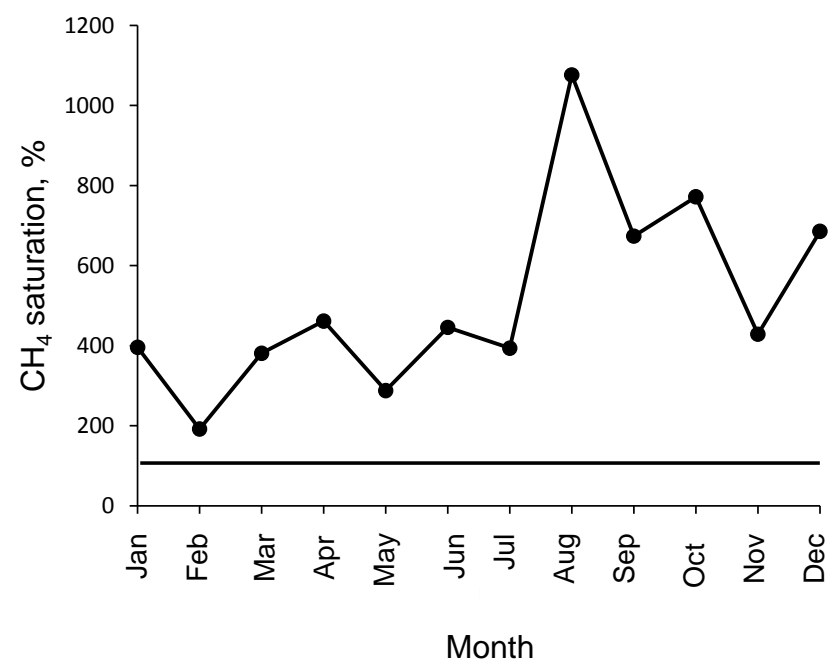

Fig. 4. Monthly mean $\mathrm{CH}_{4}$ surface saturations at Boknis Eck. The vertical bold line indicates equilibrium with the atmosphere (i.e. $100 \%$ saturation).

sonality of sedimentary methanogenesis, we focus the following discussion on the bottom layer $(25 \mathrm{~m})$. We detected a bimodal seasonal distribution of the mean monthly $\left[\mathrm{CH}_{4}\right]$ at $25 \mathrm{~m}$ with two pronounced maxima in late spring (March) and early autumn (September) (Fig. 5). The mean monthly chlorophyll a in $25 \mathrm{~m}$ showed a bimodal variability with maxima in autumn/spring (November-February) and summer (August) which coincide with the sedimentation events of the autumn/spring and summer blooms. The seasonal $\left[\mathrm{CH}_{4}\right]$ maxima in the bottom layer seem to be linked to both chlorophyll at $25 \mathrm{~m}$ and Secchi depth with a time lag of one month (Fig. 6). The correlation of $\left[\mathrm{CH}_{4}\right]$ with chlorophyll was significant at a significance level $(\alpha)$ of $0.05(r=0.67$, $n=10$ ), whereas the correlation with Secchi depth was significant at $\alpha>0.05(r=0.56, n=10)$. Our results indicate that the major drivers of the seasonality of $\left[\mathrm{CH}_{4}\right]$ in the water column are the phytoplankton blooms which deliver organic material to the sediments leading in turn to enhanced sedimentary $\mathrm{CH}_{4}$ formation (Treude et al., 2005) with a time lag of a month. Because the second (i.e. the early autumn) maximum of $\left[\mathrm{CH}_{4}\right]$ in the bottom layer is more pronounced and it is concurrent with the hypoxic event, it seems reasonable to suggest that hypoxia in conjunction with the occurrence of sedimenting organic material promotes the sedimentary $\mathrm{CH}_{4}$ release at BE: during the hypoxic event, sedimentary methanogenesis at $\mathrm{BE}$ is significantly enhanced as has been shown by Treude et al. (2005). We conclude, therefore, that the hypoxic events at $\mathrm{BE}$ modulate (enhance) the sedimentary $\mathrm{CH}_{4}$ release but they are not the prime cause of the $\mathrm{CH}_{4}$ release to the water column which seems to be the sedimenting organic material. 


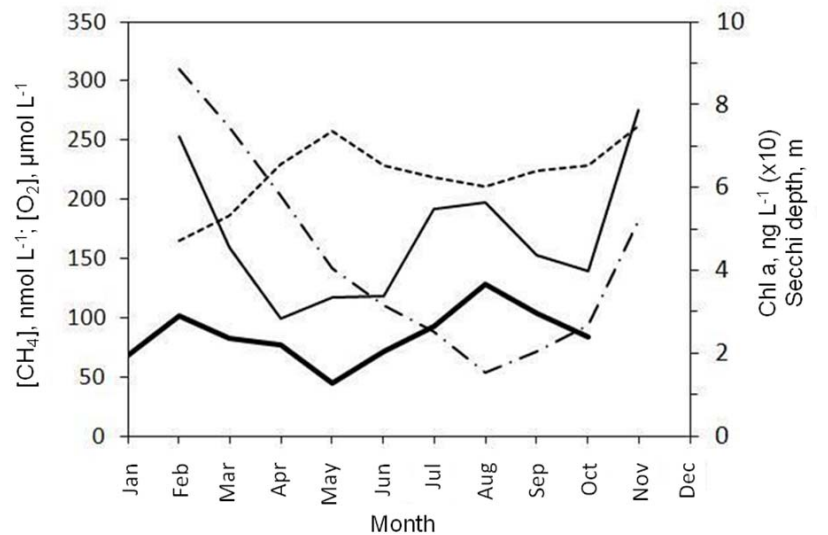

Fig. 5. Mean seasonal variability of $\mathrm{O}_{2}$ (dashed dotted line), chlorophyll (thin black line), Secchi depth (dashed line) and $\mathrm{CH}_{4}$ (bold line) at $25 \mathrm{~m}$ at Boknis Eck. The data from 2006-2008 were averaged to yield mean monthly values and smoothened with a 3-point moving average. Note that the $\mathrm{CH}_{4}$ data were shifted back by one month.

The computed mean $\mathrm{CH}_{4}$ flux densities for the sampling period 2006-2008 were 6.3 and $14.7 \mu \mathrm{mol} \mathrm{m}^{-2} \mathrm{~d}^{-1}$. This is in reasonable agreement with a rough estimate of the $\mathrm{CH}_{4}$ ebullition flux from the sediment to the overlying water column in the range of 3-20 $\mu \mathrm{mol} \mathrm{m}{ }^{-2} \mathrm{~d}^{-1}$ (Jackson et al., 1998). Additional source or sink terms such as advection of $\left[\mathrm{CH}_{4}\right]$ or aerobic $\mathrm{CH}_{4}$ oxidation in the water column may contribute to the $\left[\mathrm{CH}_{4}\right]$ distribution at $\mathrm{BE}$ as well, however, these processes have not been quantified at BE yet.

\section{Summary}

Sedimentary release of $\mathrm{CH}_{4}$ determined the $\mathrm{CH}_{4}$ concentrations in the water column at the Boknis Eck time series station during the sampling period from June 2006 to November 2008. The water column at BE was always supersaturated with $\mathrm{CH}_{4}$, and therefore, $\mathrm{BE}$ was a source of $\mathrm{CH}_{4}$ to the atmosphere throughout the sampling period. Enhanced release of $\mathrm{CH}_{4}$ to the atmosphere occurs when the $\mathrm{CH}_{4}$ accumulated in the hypoxic bottom layer during summer is brought to the surface by mixing of the water column in late summer/autumn. We did not detect a straightforward relationship between periods of enhanced $\mathrm{CH}_{4}$ in the bottom layers and hypoxic events. Indeed we found a bimodal seasonality of $\left[\mathrm{CH}_{4}\right]$ in the bottom layer with two maxima in March and September. The sedimentary release of $\mathrm{CH}_{4}$ seemed to be mainly triggered by sedimenting organic material from phytoplankton blooms. Therefore, we conclude that future $\mathrm{CH}_{4}$ emissions from $\mathrm{BE}$ will be determined by the intensity of phytoplankton blooms, which in turn will be influenced by the future trends in nutrient inputs (i.e. eutrophication). Hypoxic events have only a modulating effect on the
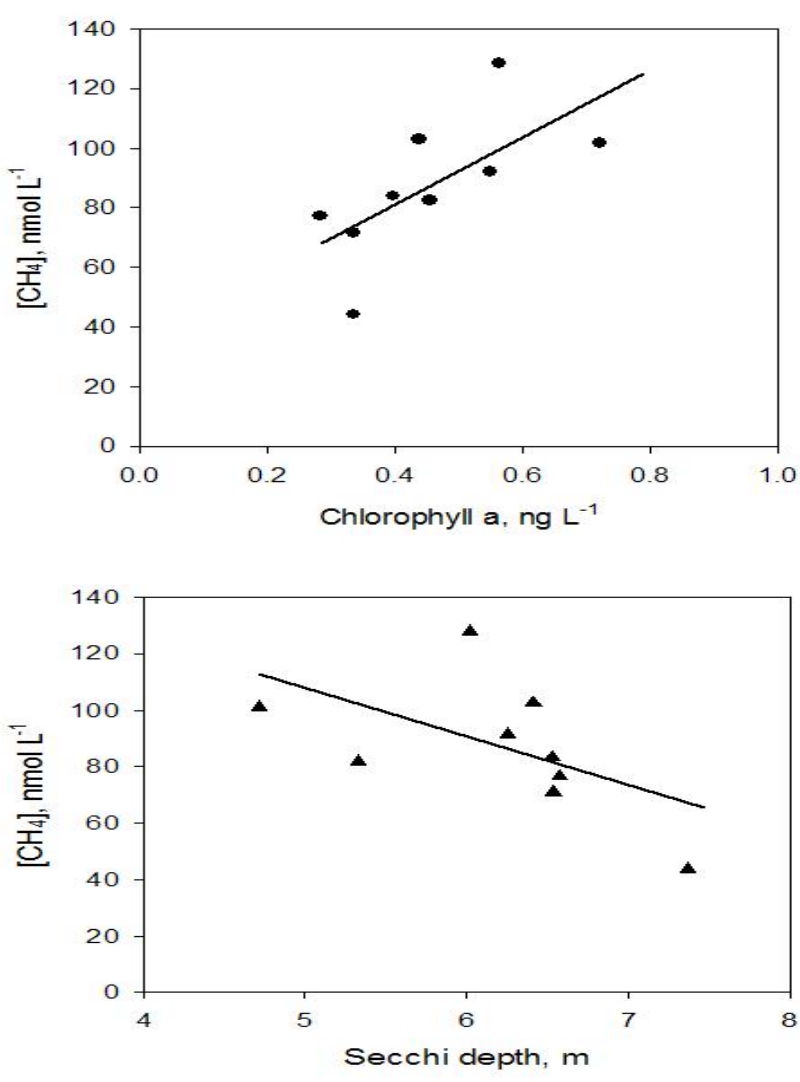

Fig. 6. Mean monthly $\mathrm{CH}_{4}$ vs. chlorophyll (upper panel) and $\mathrm{CH}_{4}$ vs. Secchi depth (lower panel). The mean monthly $\mathrm{CH}_{4}$ and chlorophyll data were calculated for $25 \mathrm{~m}$. Note that the $\mathrm{CH}_{4}$ data were shifted by one month (see Fig. 4) to account for the apparent time lag of one month.

enhancement of methanogenesis in the sediments. The time series study presented here (and time series of dissolved $\mathrm{CH}_{4}$ in other coastal regions worldwide, for example off Chile, Farías et al., 2009) seem to be a valuable tool to monitor $\mathrm{CH}_{4}$ emissions from coastal areas in order to infer the potential effects of eutrophication and climate change for the long-term trends of coastal $\mathrm{CH}_{4}$ emissions to the atmosphere.

Acknowledgements. We thank the captains and crews of R/V Littorina and R/V Polarfuchs for their continuous support. Moreover, we thank the many enthusiastic students who took part in the measurement campaigns to $\mathrm{BE}$ as part of their practical course in marine chemistry. We acknowledge the constructive comments by Laura Farías and an anonymous referee which helped improve the manuscript. The Boknis Eck Time Series Station is run by the Forschungsbereich Marine Biogeochemie of the IFM-GEOMAR, Kiel: http://www.ifm-geomar.de/index.php?id=bokniseck.

Edited by: S. W. A. Naqvi 


\section{References}

Abegg, F. and Anderson, A. L.: The acoustic turbid layer in muddy sediments of Eckernfoerde Bay, western Baltic Sea: Methane concentrations, saturation and bubble characteristics, Mar. Geol., 137, 137-147, 1997.

Bange, H. W.: Nitrous oxide and methane in European coastal waters, Estuarine, Coast. Shelf Sci., 70, 361-374, 2006.

Bange, H. W., Bartell, U. H., Rapsomanikis, S., and Andreae, M. O.: Methane in the Baltic and North Seas and a reassessment of the marine emissions of methane, Global Biogeochem. Cy., 8, 465-480, 1994.

Bange, H. W., Bell, T. G., Cornejo, M., Freing, A., Uher, G., Upstill-Goddard, R. C., and Zhang, G.: MEMENTO: A proposal to develop a database of marine nitrous oxide and methane measurements, Environ. Chem., 6, 195-197, 2009.

Bange, H. W., Dahlke, S., Ramesh, R., Meyer-Reil, L.-A., Rapsomanikis, S., and Andreae, M. O.: Seasonal study of methane and nitrous oxide in the coastal waters of the southern Baltic Sea, Estuarine, Coast. Shelf Sci., 47, 807-817, 1998.

Bussmann, I. and Suess, E.: Groundwater seepage in Eckernförde Bay (Western Baltic Sea): Effect on methane and salinity distribution of the water column, Cont. Shelf Res., 18, 1795-1806, 1998.

Cicerone, R. J. and Oremland, R. S.: Biogeochemical aspects of atmospheric methane, Global Biogeochem. Cy., 2, 299-327, 1988.

David, H. A.: Further applications of range to analysis of variance, Biometrika, 38, 393-409, 1951.

Díaz, R. J. and Rosenberg, R.: Spreading dead zones and consequences for marine ecosystems, Science, 321, 926-929, 2008.

Dlugokencky, E. J., Myers, R. C., Lang, P. M., Masarie, K. A., Crotwell, A. M., Thoning, K. W., Hall, B. D., Elkins, J. W., and Steele, L. P.: Conversion of NOAA atmospheric dry air $\mathrm{CH}_{4}$ mole fractions to a gravimetrically prepared standard scale, J. Geophys. Res., 110, D18306, doi:10.1029/2005JD006035, 2005.

Farías, L., Fernández, C., Faúndez, J., Cornejo, M., and Alcaman, M. E.: Chemolithoautotrophic production mediating the cycling of the greenhouse gases $\mathrm{N}_{2} \mathrm{O}$ and $\mathrm{CH}_{4}$ in an upwelling ecosystem, Biogeosciences, 6, 3053-3069, 2009, http://www.biogeosciences.net/6/3053/2009/.

Hansen, H. P., Giesenhagen, H. C., and Behrends, G.: Seasonal and long-term control of bottom water oxygen deficiency in a stratified shallow-coastal system, ICES J. Mar. Sci. Suppl., 56, 65-71, 1999.

Jackson, D. R., Williams, K. L., Wever, T. F., Friedrichs, C. T., and Donelson Wright, L.: Sonar evidence for methane ebullition in Eckernförde Bay, Cont. Shelf Res., 18, 1893-1915, 1998.

Jähne, B., Heinz, G., and Dietrich, W.: Measurements of the diffusion coefficients of sparingly soluble gases in water, J. Geophys. Res.h, 92, 10767-10776, 1987.
Kock, A.: Methane measurements in selected ocean areas: Eastern tropical North Atlantic Ocean and southwestern Labrador Sea, Diploma thesis, Kiel University, Kiel, 106 pp., 2007.

Malakoff, D.: Death by suffocation in the Gulf of Mexico, Science, 281, 190-192, 1998.

Naqvi, S. W. A., Bange, H. W., Farías, L., Monteiro, P. M. S., Scranton, M. I., and Zhang, J.: Coastal hypoxia/anoxia as a source of $\mathrm{CH}_{4}$ and $\mathrm{N}_{2} \mathrm{O}$, Biogeosciences Discuss., 6, 9455-9523, 2009, http://www.biogeosciences-discuss.net/6/9455/2009/.

Rabalais, N. N., Díaz, R. J., Levin, L. A., Turner, R. E., Gilbert, D., and Zhang, J.: Dynamics and distribution of natural and human-caused coastal hypoxia, Biogeosciences Discussion, 6, 9359-9453, 2009.

Raymond, P. A. and Cole, J. J.: Gas exchange in rivers and estuaries: Choosing a gas transfer velocity, Estuaries, 24, 312-317, 2001.

Rigby, M., Prinn, R. G., Fraser, P. J., Simmonds, P. G., Langenfels, R. L., Huang, J., Cunnold, D. M., Steele, L. P., Krummel, P. B., Weiss, R. F., O’Doherty, S., Salameh, P. K., Wang, H. J., Harth, C. M., Mühle, J., and Porter, L. W.: Renowed growth of atmospheric methane, Geophys. Res. Lett., 35, L22805, doi:10.1029/2008GL036037, 2008.

Siedler, G. and Peters, H.: Properties of sea water, in: Oceanography, edited by: Sündermann, J., Landolt-Börnstein, New Series, Springer Verlag, Berlin, 233-264, 1986.

Smetacek, V.: The annual cycle of Kiel Bight plankton: A longterm analysis, Estuaries, 8, 145-157,1985.

Smetacek, V., von Bodungen, B., Knoppers, B., Peinert, R., Pollehne, F., Stegmann, P., and Zeitzschel, B.: Seasonal stages characterizing the annual cycle of an inshore pelagic system, Rapp. P.-v. Reun. Cons. int. Explor. Mer, 183, 126-135, 1984.

Treude, T., Krüger, M., Boetius, A., and Jørgensen, B. B.: Environmental control on anaerobic oxidation of methane in gassy sediments of Eckernförde Bay (German Baltic), Limnol. Oceanogr., 50, 1771-1786, 2005.

UNEP: The nitrogen cascade: Impacts of food and energy production, in: Global Environment Outlook Year Book 2003, edited by: UNEP, Nairobi, Kenya, 55-60, 2004.

UNEP: Marine and coastal ecosystems and human well-being: A synthesis report based on the findings of the Millennium Ecosystem Assessment, UNEP, Nairobi, 76, 2006.

Whiticar, M. J.: Diagentic relationship of methanogenesis, nutrients, acoustic turbidity, pockmarks and freshwater seepages in Eckernförde Bay, Mar. Geol., 182, 29-53, 2002.

Wiesenburg, D. A. and Guinasso Jr., N. L.: Equilibrium solubilities of methane, carbon monoxide, hydrogen in water and seawater, J. Chem. Eng. Data, 24, 356-360, 1979. 